\title{
Comparative proteomics analysis of oral cancer cell lines: identification of cancer associated proteins
}

Saiful Anuar Karsani ${ }^{1,6^{*}}$, Nor Afiza Saihen ${ }^{1}$, Rosnah Binti Zain², Sok-Ching Cheong ${ }^{3,5}$ and Mariati Abdul Rahman ${ }^{4}$

\begin{abstract}
Background: A limiting factor in performing proteomics analysis on cancerous cells is the difficulty in obtaining sufficient amounts of starting material. Cell lines can be used as a simplified model system for studying changes that accompany tumorigenesis. This study used two-dimensional gel electrophoresis (2DE) to compare the whole cell proteome of oral cancer cell lines vs normal cells in an attempt to identify cancer associated proteins.

Results: Three primary cell cultures of normal cells with a limited lifespan without hTERT immortalization have been successfully established. 2DE was used to compare the whole cell proteome of these cells with that of three oral cancer cell lines. Twenty four protein spots were found to have changed in abundance. MALDI TOF/TOF was then used to determine the identity of these proteins. Identified proteins were classified into seven functional categories - structural proteins, enzymes, regulatory proteins, chaperones and others. IPA core analysis predicted that 18 proteins were related to cancer with involvements in hyperplasia, metastasis, invasion, growth and tumorigenesis. The mRNA expressions of two proteins - 14-3-3 protein sigma and Stress-induced-phosphoprotein 1 - were found to correlate with the corresponding proteins' abundance.
\end{abstract}

Conclusions: The outcome of this analysis demonstrated that a comparative study of whole cell proteome of cancer versus normal cell lines can be used to identify cancer associated proteins.

Keywords: Oral cancer, Proteomics, Cell lines, Cancer associated proteins

\section{Background}

Oral cancer is a devastating disease that ranks as the fifth most common type of cancer affecting humans worldwide [1]. Incidence and mortality rates vary widely across the world. There are approximately 500,000 new oral and pharyngeal cancer cases diagnosed annually, with three quarters being registered in developing countries $[2,3]$. The disease is highly associated with established cultural risk factors such as tobacco chewing/ smoking, alcohol consumption and betel-quid chewing [4]. In western countries, cigarette smoking and alcohol drinking are the major risk factors while betel-quid chewing and smoking are the major risk factors that

\footnotetext{
* Correspondence: saiful72@um.edu.my

'Institute of Biological Sciences, Faculty of Science, University of Malaya,

50603 Kuala Lumpur, Malaysia

${ }^{6}$ University of Malaya Centre for Proteomics Research (UMCPR), University of

Malaya, 50603 Kuala Lumpur, Malaysia

Full list of author information is available at the end of the article
}

contribute to the development of oral cancer in South Asia, Southeast Asia and Taiwan [1]. Oral cancer appears as an abnormal growth within the mouth region and this include the buccal mucosa (cheek), tongue, floor of the mouth and lip. Oral squamous cell carcinoma (OSCC) represents the highest of all oral malignancy, accounting for more than $95 \%$ of total cases reported [1,3].

There is a dearth of knowledge with regards to the development and progression of oral cancer. The exact molecular mechanisms remain unknown. However, it is known to involve the activation of oncogenes, change in expression of various proteins which would eventually lead to the development of cancer. Thus, a study of proteins that change in oral cancer will provide valuable information and add to our understanding of the disease. It may also identify candidate proteins that can potentially be utilized as biomarkers for early detection. The ability of proteomics to compare differences/changes in proteome 
profiles (including changes in post-translational modifications) which are related to tumor progression has been adapted in clinical research for the identification of biomarkers for disease such as cancer [5].

One of the main problems in performing proteomics analysis on cancerous cells is the difficulty in obtaining sufficient amounts of material to perform the analysis. The availability of cancer cell lines makes it possible to obtain an almost limitless amount of sample for proteomic analysis. Cultured cancer and normal cell lines can be used as a simplified model system for studying changes that accompany tumorigenesis. Thus, this study aims to utilize proteomics in identifying differences between proteome profiles of normal primary cultures vs oral cancer cell lines. Our results showed that such an analysis will identify cancer associated proteins.

\section{Results and discussions}

Identification of proteins with different abundance between normal primary cultures and cancer cell lines

More than 1000 individual protein spots were resolved and visualized on silver stained gels. A representative gel is shown in Figure 1. Image analysis identified 24 protein spots that exhibited significant difference in abundance $(p<0.05)$. All 24 were unambiguously identified by MALDI-TOF/TOF MS and their respective identities are shown in Table 1 . The index numbers in Table 1 correspond to the numbers in Figure 1 and they indicate the location of the proteins on the 2DE gels. From this point forward, proteins will be referred to by their abbreviated names as shown in Table 1. Table 1 includes zoomed images for all protein spots. The identified proteins were classified into seven functional categories - structural proteins, enzymes, regulatory proteins, chaperones and others. For almost all identified proteins, the experimental and theoretical pI and molecular weights were matched.

When proteins with different abundance in oral cancer were subjected to analysis using IPA, 18 were predicted to be related to cancer with involvements in hyperplasia, metastasis, invasion, growth and tumorigenesis. Table 2 shows a list of proteins known to have roles in various cancers based on IPA. Figure 2 shows a graphical representation of the predicted molecular relationships between these proteins. The predicted network involved interplay between the various proteins and suggested that changes in abundance of these proteins may influence the function of other proteins within the network. IPA also predicted that most of the proteins were of cytosolic origin.

\section{Coordinate regulation of proteins with similar function}

Two groups of proteins - detoxification enzymes and proteasome activator complex - appeared to show coordinate change in protein abundance in oral cancer.

\section{Detoxification enzymes}

Four enzymes involved in the protection of cells against oxidative stress - Lactoylglutathione lyase (LGUL), Peroxiredoxin-4 (PRDX4), Glutathione S-

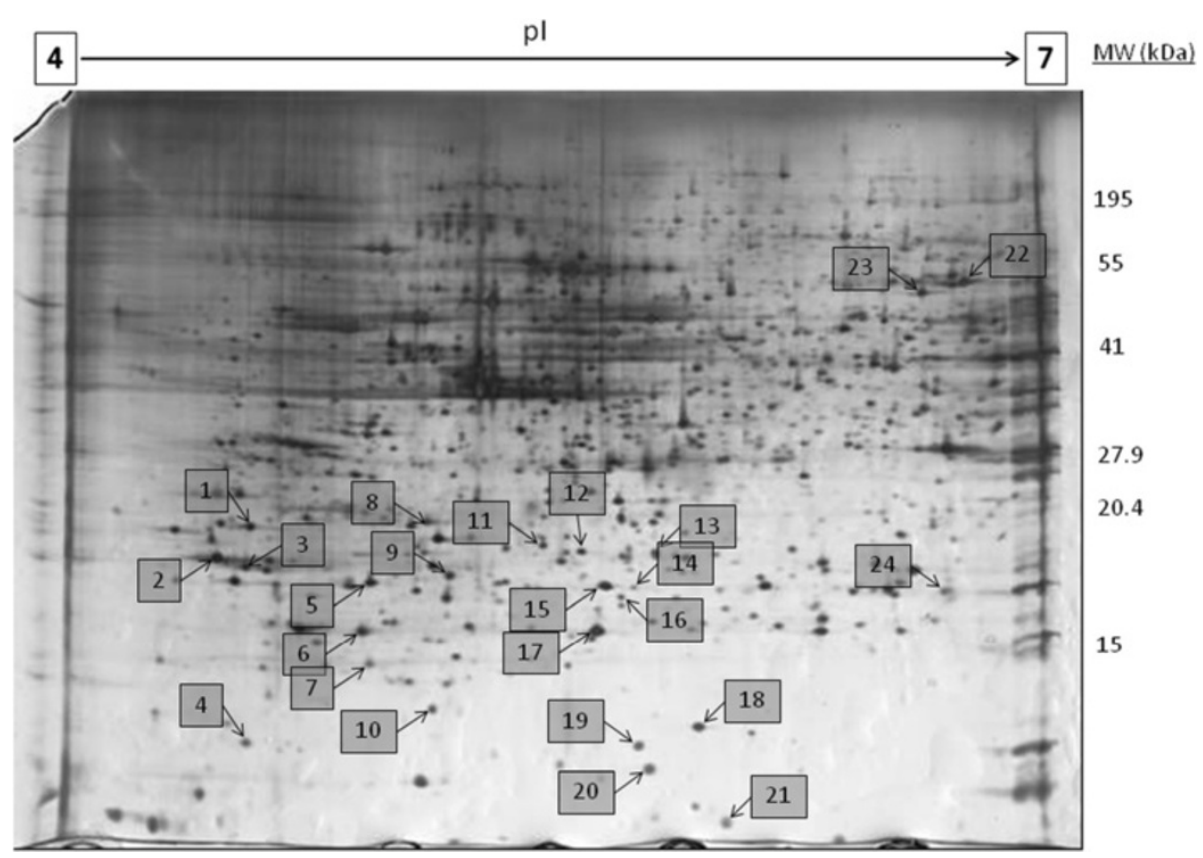

Figure 1 Representative 2DE gel of whole cell proteome of cell lines. The whole cell protein of normal primary cultures and cancer cell lines were resolved by 2DE pl 4-7, 11\% second dimension polyacrylamide gel. Proteins with different abundance are shown as numbered spots. The numbers correspond to Spot Number in Table 1. 
Table 1 List of proteins with different abundance in cancer cell lines

\begin{tabular}{|c|c|c|c|c|c|c|c|c|}
\hline \multicolumn{2}{|c|}{ Protein name } & \multirow{3}{*}{$\begin{array}{l}\text { Ascension number } \\
\text { (Swissprot)/matched } \\
\text { 2D coordinates } \\
\text { (World-2DPAGE portal) }\end{array}$} & \multicolumn{2}{|c|}{$\mathrm{MW} / \mathrm{pl}$} & \multirow[t]{3}{*}{$\begin{array}{l}\text { Peptides } \\
\text { (\% cov) }\end{array}$} & \multirow[t]{3}{*}{$\begin{array}{l}\text { Relative change } \\
\text { vs normal }\end{array}$} & \multicolumn{2}{|c|}{$\begin{array}{l}\text { Zoomed in gel image showing } \\
\text { representative spots }\end{array}$} \\
\hline \multicolumn{2}{|c|}{ Abbreviation } & & \multirow[b]{2}{*}{ Theory } & \multirow[b]{2}{*}{ Experimental } & & & \multirow[b]{2}{*}{ Normal } & \multirow[b]{2}{*}{ Cancer } \\
\hline & & & & & & & & \\
\hline \multicolumn{9}{|c|}{ Structural } \\
\hline \multirow[t]{2}{*}{20} & Stathmin (Phosphoprotein p19) & P16949 /SPOT 2D-001YH8 & $17.3 / 5.76$ & $>15.0 / 5.7$ & $4(18 \%)$ & +1.6 & & \\
\hline & STMN1 & & & & & & & \\
\hline \multirow[t]{4}{*}{1} & Tropomyosin alpha-3 chain & P06753 / & $32.8 / 4.68$ & $>30.0 / 4.6$ & $6(13 \%)$ & -1.5 & & \\
\hline & & SPOT 2D-001EM1 & & & & & & \\
\hline & & SPOT 2D-001YBH & & & & & & \\
\hline & TPM3 & SPOT 2D-001JNO & & & & & & \\
\hline \multirow[t]{3}{*}{4} & Myosin regulatory light chain-2 & P19105 / & 19.8/4.67 & $>15.0 / 4.60$ & $5(17 \%)$ & -1.9 & & \\
\hline & & SPOT 2D-001JUH & & & & & & \\
\hline & ML12A & SPOT 2D-001JUS & & & & & & \\
\hline \multicolumn{9}{|c|}{ Enzymes } \\
\hline \multirow[t]{2}{*}{6} & $\begin{array}{l}\text { Lactoylglutathione lyase } \\
\text { (Glyoxalase I). (EC 4.4.1.5) }\end{array}$ & Q04760 / & $20.8 / 5.12$ & $>20.0 / 5.00$ & $10(22 \%)$ & +7.7 & & \\
\hline & LGUL & $\mathrm{n} / \mathrm{a}$ & & & & & & \\
\hline \multirow[t]{2}{*}{24} & $\begin{array}{l}\text { Triosephosphate isomerase } \\
\text { (EC 5.3.1.1) }\end{array}$ & P60174 / & $26.7 / 6.45$ & $>25.0 / 6.5$ & $5(28 \%)$ & +2.5 & & \\
\hline & TPIS & SPOT 2D-0003MP & & & & & & \\
\hline \multirow[t]{2}{*}{18} & $\begin{array}{l}\text { Nucleoside diphosphate } \\
\text { kinase A (EC 2.7.4.6) }\end{array}$ & P15531 / & $17.1 / 5.83$ & $>15.0 / 5.8$ & $8(31 \%)$ & +1.5 & & \\
\hline & NDKA & $\mathrm{n} / \mathrm{a}$ & & & & & & \\
\hline \multirow[t]{2}{*}{21} & $\begin{array}{l}\text { Ubiquitin-conjugating } \\
\text { enzyme E2 N } \\
\text { (EC 6.3.2.19) }\end{array}$ & P61088 / & $17.1 / 6.13$ & $>15.0 / 5.9$ & $6(23 \%)$ & +2.6 & & \\
\hline & UBE2N & $\mathrm{n} / \mathrm{a}$ & & & & & & \\
\hline
\end{tabular}


Table 1 List of proteins with different abundance in cancer cell lines (Continued)

16 Gamma-glutamylcyclotransferase $\quad 075223 / \quad 21.0 / 5.07 \quad>20.0 / 5.0$

(EC 2.3.2.4)

GGCT

4 Peroxiredoxin-4

(EC 1.11.1.15)

PRDX4

19 Superoxide dismutase

[CU-Zn] (EC 1.15.1.1)

SODC

17 Glutathione S-transferase

P (GST class-pi).

(EC 2.5.1.18)

GSTP

11 Proteasome subunit beta type 4 precurso (EC 3.4.25.1)

PSB4

Regulatory proteins

3 14-3-3 protein beta/alpha 1433B

12 Prohibitin

PHB

13 Proteasome activator complex subunit 1

PSME1

$28.7 / 5.78$

$>25.0 / 5.70$

$2(4 \%)$

SPOT 2D-001YC7

P00441 /

$15.9 / 5.70 \quad>15.0 / 5.70$

$5(24 \%)$

SPOT 2D-000ZX

P09211 /

23.3/5.43

$>25 / 5.6$

8 (22\%)

SPOT 2D-0003Q

SPOT 2D-00085X

$$
\text { P28070 / }
$$

$29.2 / 5.72$

29.0/5.7

$6(15 \%)$

SPOT 2D-000D4M

P31946 /

28.0/4.70

$>25.0 / 4.50$

$6(4 \%)$

n/a

P35232 /

29.8/5.57

$>25.0 / 5.60$

$5(12 \%)$

SPOT 2D-001EOL

.

$+2.5$

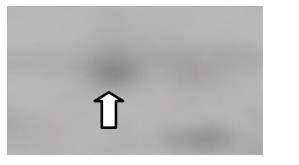

仓
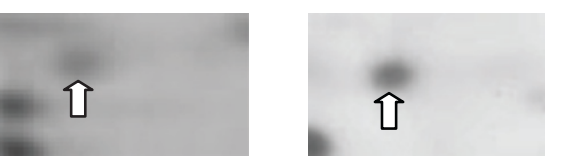

$+1.4$
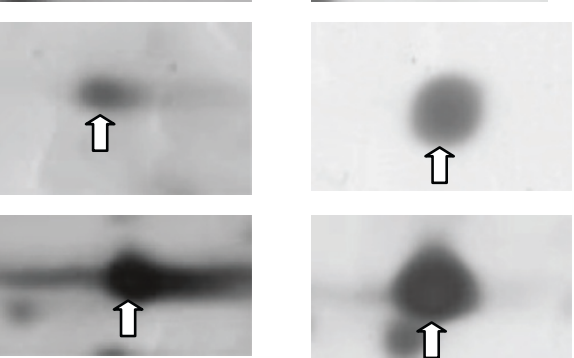

$+1.4$

.

$+1.6$

+1.
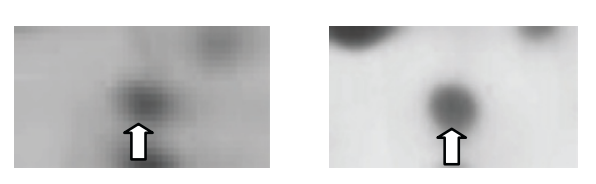

$+1.8$
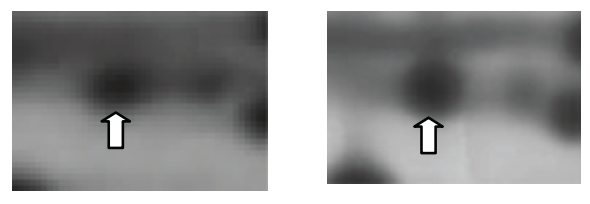

$+1.6$

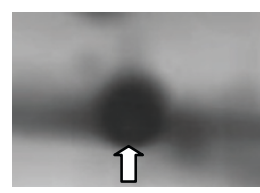

$-1.7$
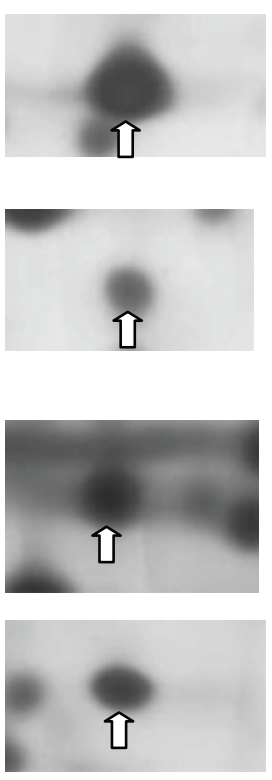

仓

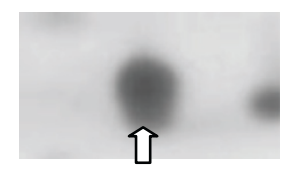


Table 1 List of proteins with different abundance in cancer cell lines (Continued)

$\begin{array}{llll}16 & \text { Proteasome activator } & \text { Q9UL46/ 27.3/5.44 } & >30.0 / 5.4\end{array}$

complex

PSME2

2 14-3-3 protein

sigma (Stratifin)

14335

22 Stress-induced-phosphoprotein 1 STIP1

10 Interleukin-1 receptor antagonist protein precursor

ILIRA

5 Rho GDP-dissociation

inhibitor 1

GDIR

9 Ran-specific GTPase-activating protein

RANG

Chaperones

15 Heat-shock protein

beta-

HSPB1

$23 \quad$ T-complex protein 1 subunit zeta-2

TCPW $\mathrm{n} / \mathrm{a}$

P31947 /

$27.8 / 4.68$

$>25.0 / 4.50$

$9(24 \%)$

SPOT 2D-001EP6

P31948/

n/a

$62.6 / 6.4$

$>55.0 / 6.50$

$11(12 \%)$

$+2.1$

$18510 /$

n/a

P52565 /

23.2/5.02

30.0/5.0

$4(14 \%)$

$\mathrm{n} / \mathrm{a}$

P43487 /

23.3/5.19

$30 / 5.2$

$5(18 \%)$

n/a

P04792 / SPOT 2D-001JQ

SPOT 2D-001JQP

Q92526 /

$57.7 / 6.63$

$>55.0 / 6.8$

$2(2 \%)$

n/a

$+1.3$

$+1.8$

$22.8 / 6.00 \quad>20.0 / 5.8 \quad 11(32 \%)$
$-23$

(20)

ษ
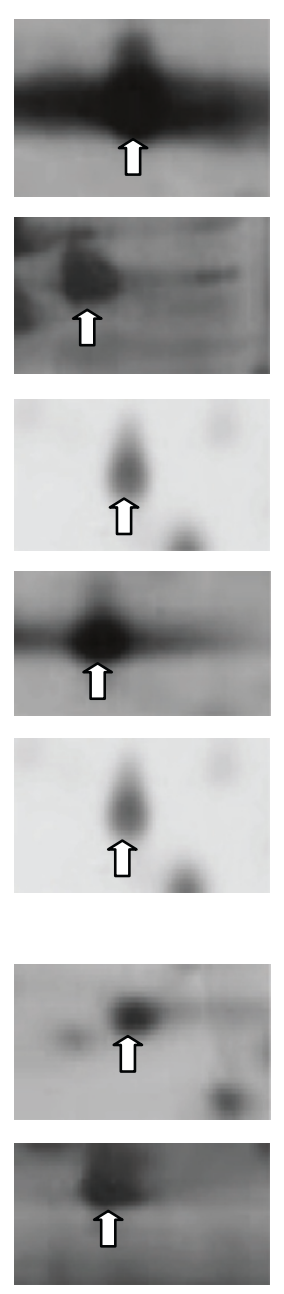

ษ

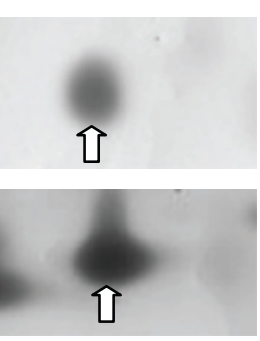

饣

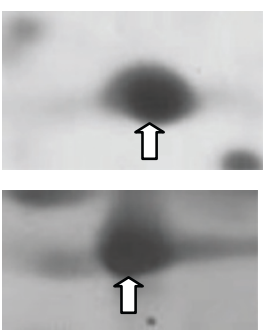


Table 1 List of proteins with different abundance in cancer cell lines (Continued)

Others

8 Chloride intracellular

channel protein 1

000299 /

26.9/5.09

$>30.0 / 5.1$

$14(46 \%)$

$-1.7$

(membrane associated)

SPOT 2D-001YBL

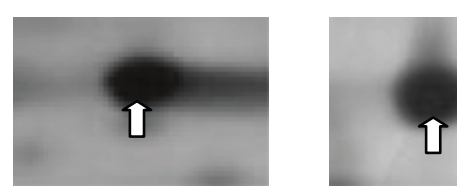

The proteins were grouped into five functional categories - structural proteins, enzymes, regulatory proteins, chaperones and others. The accession number (swiss-prot) and matched 2D coordinates, molecular weight and $\mathrm{pl}$ (theoretical and experimental), number of matched peptides, percentage coverage, relative change vs normal and zoomed in gel image showing representative spots are shown. 
Table 2 Proteins that are known to be cancer associated based on IPA

\begin{tabular}{|c|c|c|c|c|}
\hline Category & $\begin{array}{l}\text { Functions } \\
\text { annotation }\end{array}$ & p-value & Molecules & $\begin{array}{c}\text { \# of } \\
\text { molecules }\end{array}$ \\
\hline Cancer & Cervical tumor & $1.55 \mathrm{E}-04$ & GSTP1, HSPB1, PHB, TPM3 & 4 \\
\hline Cancer & Breast cancer & $1.82 \mathrm{E}-04$ & GGCT, GLO1, GSTP1, NME1, PHB, RANBP1, SOD1, TPI1 & 8 \\
\hline Cancer & $\begin{array}{l}\text { Nodular hyperplasia } \\
\text { of liver }\end{array}$ & $1.25 \mathrm{E}-03$ & SOD1 & 1 \\
\hline Cancer & Hematological neoplasia & $1.89 \mathrm{E}-03$ & CCT6B, GSTP1, NME1, PSME1, STIP1, STMN1 & 6 \\
\hline Cancer & Lymphohematopoietic cancer & $2.21 \mathrm{E}-03$ & CCT6B, GSTP1, NME1, PSME1, STIP1, STMN1 & 6 \\
\hline Cancer & Cervical cancer & $2.44 \mathrm{E}-03$ & GSTP1, HSPB1, TPM3 & 3 \\
\hline Cancer & Multiplicity of benign tumor & $2.50 \mathrm{E}-03$ & GSTP1 & 1 \\
\hline Cancer & Neuroblastoma & 3.33E-03 & GSTP1, NME1 & 2 \\
\hline Cancer & Epidermal hyperplasia & $4.24 \mathrm{E}-03$ & PHB, RANBP1 & 2 \\
\hline Cancer & Metastasis of melanoma & 4.99E-03 & IL1RN & 1 \\
\hline Cancer & Gastric cancer & $5.75 \mathrm{E}-03$ & GSTP1, IL1RN, PHB & 3 \\
\hline Cancer & $\begin{array}{l}\text { Digestive organ } \\
\text { tumor }\end{array}$ & $6.00 \mathrm{E}-03$ & GSTP1, IL1RN, NME1, PHB, SFN, SOD1, STIP1, TPI1 & 8 \\
\hline Cancer & Invasion of trophoblast & $7.48 \mathrm{E}-03$ & NME1 & 1 \\
\hline Cancer & Urothelial bladder carcinoma & $7.48 \mathrm{E}-03$ & GSTP1 & 1 \\
\hline Cancer & $\begin{array}{l}\text { Non-small cell } \\
\text { lung cancer }\end{array}$ & 7.89E-03 & GSTP1, MYL12A, STMN1 & 3 \\
\hline Cancer & Cancer & $8.08 \mathrm{E}-03$ & $\begin{array}{l}\text { CCT6B, GGCT, GLO1, GSTP1, HSPB1, IL1RN, MYL12A, NME1, } \\
\text { PHB, PSME1, RANBP1, SFN, SOD1, STIP1, STMN1, TPI1, TPM3 }\end{array}$ & 17 \\
\hline Cancer & Liver cancer & $9.35 \mathrm{E}-03$ & GSTP1, NME1, SOD1, TPI1 & 4 \\
\hline Cancer & Immortalization of keratinocytes & 9.96E-03 & SFN & 1 \\
\hline Cancer & Invasion of extracellular matrix & 1.12E-02 & NME1 & 1 \\
\hline Cancer & Neoplasia of cells & $1.21 \mathrm{E}-02$ & NME1, PHB, SFN & 3 \\
\hline Cancer & Hematologic cancer & 1.27E-02 & GSTP1, NME1, PSME1, STIP1 & 4 \\
\hline Cancer & Hereditary diffuse gastric cancer & 1.37E-02 & IL1RN & 1 \\
\hline Cancer & Growth of secondary tumor & $1.49 \mathrm{E}-02$ & IL1RN & 1 \\
\hline Cancer & Incidence of hepatocellular carcinoma & $1.49 \mathrm{E}-02$ & SOD1 & 1 \\
\hline Cancer & Quantity of papilloma & $1.61 \mathrm{E}-02$ & GSTP1 & 1 \\
\hline Cancer & Metastasis of cells & $1.71 \mathrm{E}-02$ & NME1, PHB & 2 \\
\hline Cancer & Hepatocellular carcinoma & $2.21 \mathrm{E}-02$ & NME1, SOD1, TPI1 & 3 \\
\hline Cancer & Follicular adenoma & $2.23 \mathrm{E}-02$ & GSTP1 & 1 \\
\hline Cancer & Waldenstrom's macroglobulinemia & $2.26 \mathrm{E}-02$ & NME1,STIP1 & 2 \\
\hline Cancer & Acute myeloid leukemia & $2.31 \mathrm{E}-02$ & GSTP1, PSME1 & 2 \\
\hline Cancer & Tumorigenesis of colon cancer cell lines & 2.35E-02 & SFN & 1 \\
\hline Cancer & Metastasis of cancer cells & $2.96 \mathrm{E}-02$ & $\mathrm{PHB}$ & 1 \\
\hline Cancer & Infection of cervical cancer cell lines & 3.05E-02 & PSME2, RANBP1, STIP1 & 3 \\
\hline Cancer & Growth of melanoma & $3.08 \mathrm{E}-02$ & IL1RN & 1 \\
\hline Cancer & Metastasis of melanoma cell lines & $3.20 \mathrm{E}-02$ & NME1 & 1 \\
\hline
\end{tabular}

transferase P (GSTP1) and Superoxide dismutase (SODC) - were found to be in higher abundance in oral cancer. Malignant cells are in general under increased oxidative stress [6-8]. Thus, an increase of enzymes involved in protection against oxidative stress may be a mechanism to tolerate such stress.
LGUL Catalyzes the conversion of hemimercaptal, formed from methylglyoxal and glutathione, to $\mathrm{S}$ lactoylglutathione. Inhibitors of LGUL have been proposed as possible antitumor agents that function by inducing elevated levels of methylglyoxal in cancer cells. Methylglyoxal has been shown to inhibit the 


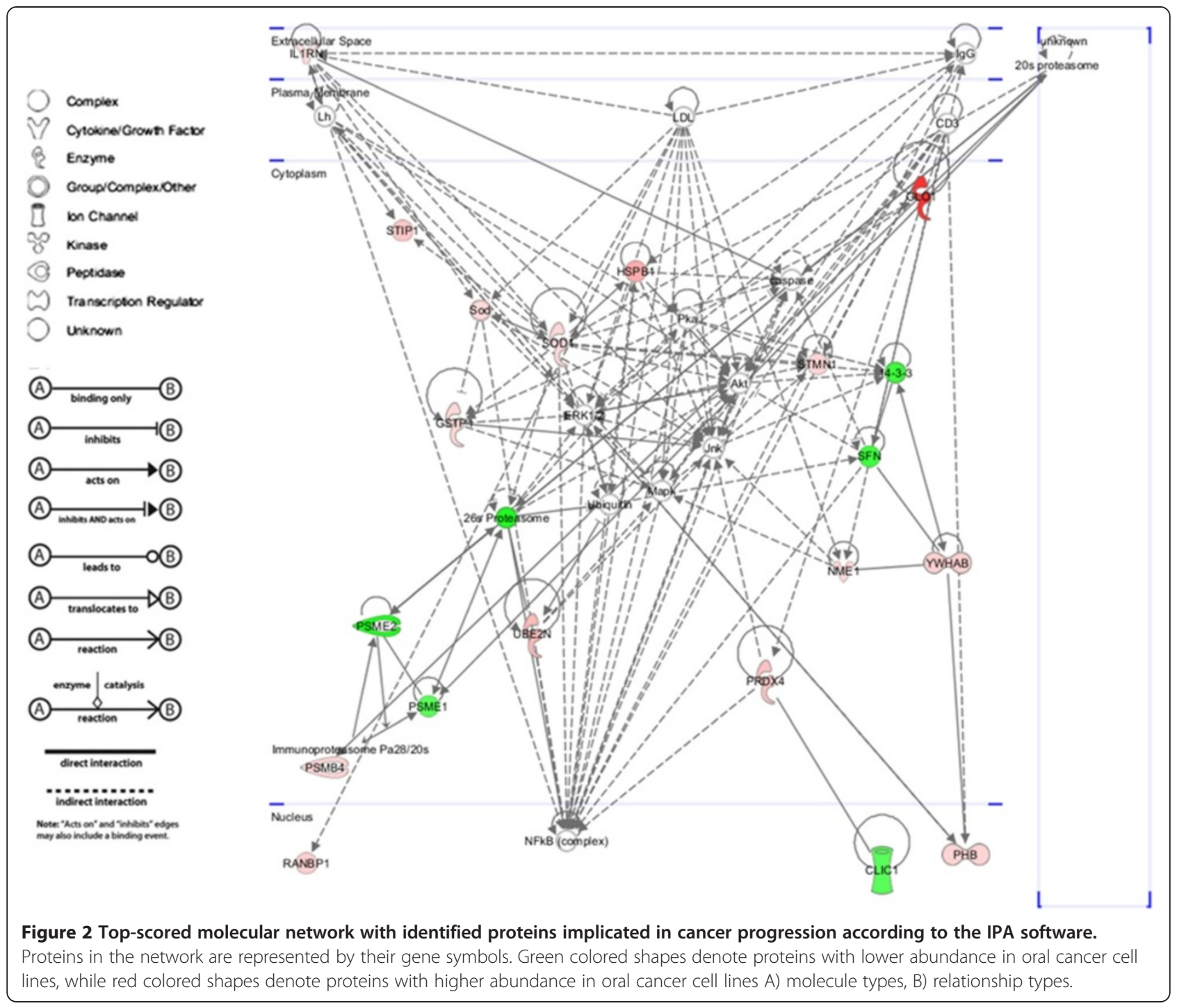

growth of human leukaemia 60 cells in culture [9]. It has also been shown that LGUL inhibitors may also be a drug resistance-reversing agent [10]. Increase of LGUL level has been found in drug-resistant tumor cells and in invasive ovarian cancer and breast cancer [11].

PRDX4 is involved in the redox regulation of the cell. The level of peroxiredoxins (in particular PRDX3, PRDX4 and PRDX5) has been shown to be increased in cancer, suggesting the induction of PRDX as a response to increased production of reactive oxygen species in carcinomatous tissue [12].

GSTP1 conjugates reduced glutathione to a wide number of exogenous and endogenous hydrophobic electrophiles. It plays an important role in the protection of cells from the products of oxidative stress as well as from several environmental carcinogens. The GSTP1 gene has been shown to be overexpressed in many human tumors [13].
SODC destroys radicals which are normally produced within the cells and which are toxic to biological systems. The level of SODC has been shown to increase in a number of cancers [14-16].

\section{Proteasome activator complex}

Proteasome activator complex subunit 1 (PSME1) and proteasome activator complex subunit 2 (PSME2) are implicated in immunoproteasome assembly and is required for efficient antigen processing. IPA showed that both proteins also interact and influence the function of the $26 \mathrm{~s}$ and $20 \mathrm{~s}$ proteaseome. The proteasome is a multicatalytic proteinase complex that is responsible for the degradation of most intracellular proteins, including proteins that are crucial to cell cycle regulation and programmed cell death, or apoptosis. Targeting the proteasome is being investigated as a useful anticancer strategy [17]. PSME has also been proposed as a potential 

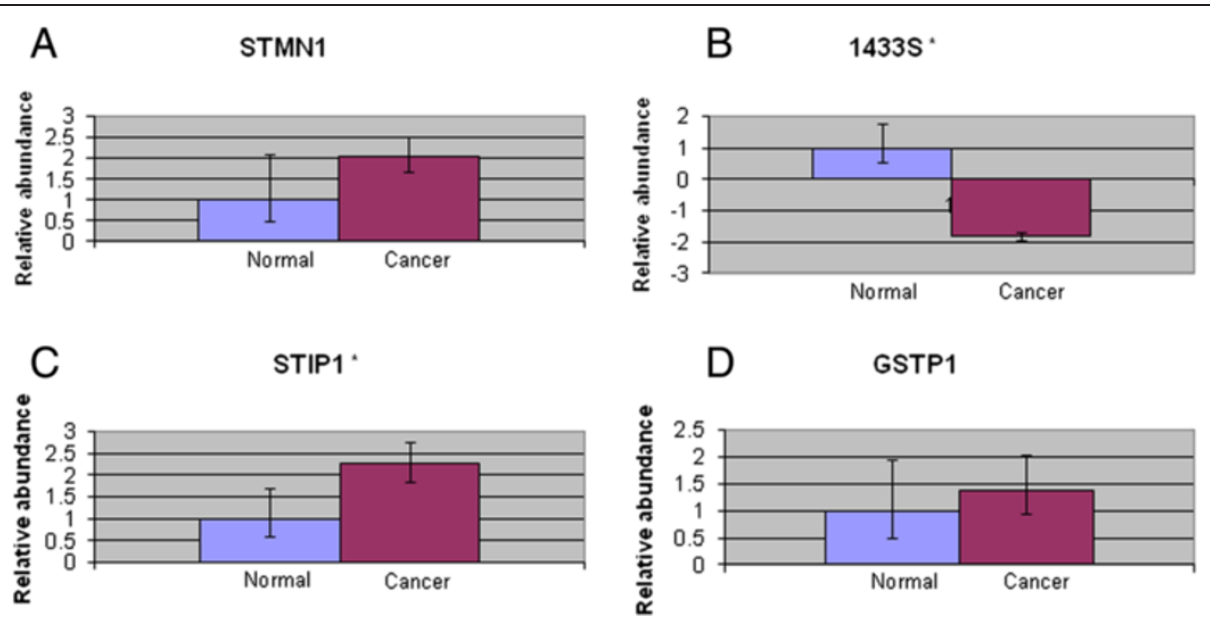

Figure 3 Results of quantitative RT-PCR showing relative expressions of STMN1, 1433S, STIP1 and GSTP1. Total mRNA was extracted from normal and oral cancer cell lines. Quantitative RT-PCR was then performed as described. A: Relative expression of STMN1, B: Relative expression of 1433S, C: Relative expression of STIP1, D: Relative expression of GSTP1. Relative intensities of all genes of interest were determined by using $\beta$-actin as an internal standard. Results represent the mean \pm SD for three experiments. ${ }^{*} p<0.05$.

biomarker for ovarian cancer [18]. Interestingly, our proteomics analysis showed a decrease in abundance of these proteins, whereas the proteoasome activity is expected to increase in most cancers.

\section{Proteins with higher abundance in oral cancer cell line Structural protein}

Stathmin (STMN1) is involved in the regulation of the microtubule filament system where it prevents the assembly and promotes disassembly of microtubules. It has been shown to be present at high levels in a variety of human cancers and has been proposed as a potential target in cancer therapies that disrupt the mitotic apparatus [19].

\section{Enzymes}

A number of enzymes were found to be in higher abundance in cancer cell lines. Triosephosphate isomerase (TPIS) is a glycolysis enzyme that catalyzes the reversible interconversion of triosephosphate isomers - dihydroxyacetone phosphate and D-glyceraldehyde 3-phosphate. TPIS may be associated with cancer metastasis [20].

Nucleoside diphosphate kinase A (NDKA) plays a major role in the synthesis of nucleoside triphosphates other than ATP. NDKA is involved in cell proliferation, differentiation and development, signal transduction, $G$ protein-coupled receptor endocytosis, and gene expression. It has been shown to act as both a metastasis suppressor and promoter in different tumors [21].

Ubiquitin-conjugating enzyme E2 N (UBE2N) mediates the transcriptional activation of target genes. The increased abundance of UBE2N and other ubiquitin conjugating enzymes has been reported in various cancers [22-25].
Gamma-glutamylcyclotransferase (GGCT) catalyzes the formation of 5-oxoproline from gamma-glutamyl dipeptides and may play a significant role in glutathione homeostasis. It induces the release of cytochrome $\mathrm{c}$ from the mitochondria resulting in the induction of apoptosis. GGCT may be associated in the induction of apoptosis in leukemia U937 cells [26].

Proteasome subunit beta type 4 (PSB4) belongs to the proteasome multicatalytic proteinase complex. This complex is characterized by its ability to cleave peptides with Arg, Phe, Tyr, Leu, and Glu adjacent to the leaving group at neutral or slightly basic $\mathrm{pH}$.

\section{Regulatory proteins}

14-3-3 protein beta/alpha (1433B) is an adapter protein implicated in the regulation of a large spectrum of both general and specialized signaling pathways. 1433B binds to a large number of partners, usually by recognition of a phosphoserine or phosphothreonine motif. Binding will generally result in the modulation of the activity of the binding partner.

Prohibitin (PHB) has a role in regulating cell proliferation where it inhibits DNA synthesis. It has been shown to be involved in a number of different cancers [27-30].

Stress-induced-phosphoprotein 1 (STIP1) mediates the association of the molecular chaperones HSC70 and HSP90. STIP1 has been shown to be secreted by, and induces proliferation in glioma cells [31]. It has also been implicated in a number of other cancers [32-34].

Interleukin-1 receptor antagonist protein (IL1RA) inhibits the activity of IL-1 by binding to its receptor. The level of IL1RA has been shown to change in cancer [35-37].

Rho GDP-dissociation inhibitor 1 (GDIR) regulates the GDP/GTP exchange reaction of the Rho proteins by 
inhibiting the dissociation of GDP from them, and the subsequent binding of GTP to them. In cancer, GDIR has been implicated in metastasis, mediation of cancer cell motility and drug resistance [38-40].

Ran-specific GTPase-activating protein (RANG) inhibits GTP exchange on Ran and plays an essential role in nuclear transport by permitting RanGAP-mediated hydrolysis of GTP on Ran complexed to karyopherin b [41].

\section{Chaperones}

Heat-shock protein beta-1 (HSPB1) is involved in stress resistance and actin organization. Heat shock proteins (HSPs) are a large and heterogeneous group of chaperones whose synthesis can be induced by both physiological and pathological conditions, such as heat shock, oxidative stress, mitogenic signals, inflammation, infection and neoplastic transformation. Although a number of HSPs has been implicated with cancer, association of HSPB1has not been reported.

\section{Proteins with lower abundance in oral cancer cell line Structural proteins}

Tropomyosin alpha-3 chain (TPM3) binds to actin filaments in muscle and non-muscle cells. In association with the troponin omplex, it plays a central role in the calcium dependent regulation of vertebrate striated muscle contraction.

Myosin regulatory light chain-2 (ML12A) is a myosin regulatory subunit that plays an important role in regulation of both smooth muscle and non-muscle cell contractile activity via its phosphorylation. ML12A has been implicated in cytokinesis, receptor capping, and cell locomotion. Phosphorylation of ML12A has been shown to be critical in the invasiveness of metastatic cancer cells [42].

\section{Regulatory protein}

14-3-3 protein sigma, also known as stratifin (1433S) is an adapter protein implicated in the regulation of a wide variety of both general and specialized signaling pathways. $1433 \mathrm{~S}$ is a potential lymph node metastasis-related protein in lung squamous carcinoma [43].

\section{Chaperones}

T-complex protein 1 subunit zeta-2 (TCPW) is a molecular chaperon that assists in the folding of proteins upon ATP hydrolysis [44].

\section{Others}

Chloride intracellular channel protein 1 (CLIC1) is a protein that can insert into cellular membranes to form chloride ion channels. It has been shown that overexpression of CLIC1 promoted cell motility and invasion of low metastasic cell lines (GBC-SD18L) in vitro, while
RNA interference of CLIC1 decreased cell motility and invasive potency of highly metastasic cell lines (GBC$\mathrm{SD} 18 \mathrm{H})$ in vitro, suggesting that CLIC1 may play an important role in metastasis of gallbladder carcinoma [45]. CLIC1 has also been proposed as a potential biomarker $[46,47]$ and therapeutic target $[48]$ for cancer.

\section{Assessment of mRNA transcript}

Quantitative real-time PCR was performed to assess the mRNA expression of four proteins - STMN1, 1433S, STIP1 and GSTP1. These proteins were selected due the marked difference in their abundance and/or possible involvement in cancer. They also represented proteins from various functional categories. The mRNA expression of all four genes was found to correlate with its corresponding protein abundance. However, only 1433 S and STIP1 was found to be statistically significant (Figure 3 ). This suggested that these proteins may be regulated at the mRNA level.

\section{Conclusions}

We have showed that a comparative study of the oral cancer cell line proteome may identify cancer associated proteins. IPA predicted that at least 18 of these proteins were associated with cancer development and progression. At least two identified proteins (CLIC1 and PSME) have previously been proposed as potential biomarkers for cancer. Two groups of proteins (detoxification enzymes and proteasome activator complex) appeared to show coordinate change in protein abundance. Taken together, these results has demonstrated the potential of this type of study as an alternative to directly analyzing tissue samples in identifying cancer associated proteins. This study can be further extended by investigating the presence/absence of these proteins in tissue samples.

\section{Methods}

\section{Establishment of cell cultures}

This project was approved by the Medical Ethics Committee, Faculty of Dentistry, University of Malaya and endorsed by the Ministry of Health, Malaysia (DFOP1006/0041[P]). Normal tissues were derived from surgically resected tissue specimens from different impacted tooth patients. Cancerous tissues were derived from surgically resected tissue specimens from three different oral squamous cell carcinoma patients. Sample collection was performed at the Faculty of Dentistry and University Malaya Medical Centre, Kuala Lumpur Hospital and Tengku Ampuan Rahimah Hospital. All tissues were acquired after written informed consent was obtained from the patients. The oral cancer cell lines and primary cultures were derived from squamous cells and were originated from the same anatomic site (gum). Cell cultures were established as previously described $[49,50]$. 


\section{Sample preparation and protein extraction}

Cells were grown to confluence. Following trypsinization, cells were pelleted and washed $3 \times$ with PBS. The cells were then lysed by repeated freeze thawing in extraction buffer (5 M Urea, $2 \mathrm{M}$ Thiourea, 2\% SB3-10 and $2 \%$ CHAPS). Protein concentration was determined by Bradford assay using Bovine Serum Albumin as standard according to the manufacturer's instruction (Bio-Rad Laboratories).

\section{Two-Dimensional Gel Electrophoresis (2DE)}

For each cell line/primary culture, 2DE was performed in triplicate on protein samples extracted from three different passages of growth. Isoelectric focusing for 2DE was performed using an IPGphor system (Amersham Biosciences) according to the manufacturer's protocol. Briefly, IPG strips $(24 \mathrm{~cm}$ Immobiline IPG Drystrip $\mathrm{pH} 4-7)$ were rehydrated overnight using $450 \mu \mathrm{l} /$ strip urea rehydration stock solution (8 M Urea, 2\% w/v CHAPS, $0.5 \% \mathrm{v} / \mathrm{v}$ Pharmalyte/IPG Buffer pH3-10, 1\% trace bromophenol blue) without containing the sample. Protein extracts were solubilized in $80 \mu \mathrm{l}$ sample lysis buffer $(8 \mathrm{M}$ Urea, 4\% w/v CHAPS, $40 \mathrm{mM}$ Tris, $65 \mathrm{mM}$ DTT, 1\% trace bromophenol blue) and loaded into the loading cup just before running. A total of $80 \mu \mathrm{g}$ protein was loaded for analytical gels and $160 \mu \mathrm{g}$ loaded for preparative gels. Isoelectric focusing was performed for $60 \mathrm{kVh}$ with running conditions as follows: $500 \mathrm{~V}: 1$ hour, $1000 \mathrm{~V}: 1$ hour, $1000 \mathrm{~V}: 3$ hours and finally a constant $8000 \mathrm{~V}$ at $20^{\circ} \mathrm{C}$.

For the second dimension, the IPG strips were first equilibrated in $10 \mathrm{ml}$ of SDS equilibration buffer (6 M Urea, $75 \mathrm{mM}$ Tris- $\mathrm{HCl}$ pH8.8, 87\% w/w glycerol, 2\% SDS, $1 \%$ trace bromophenol blue) containing 1\% DTT for $10 \mathrm{mi}-$ nutes, followed by a second equilibration for 10 minutes in the same equlibration buffer containing 2.5\% Iodoacetamide. Equilibrated strips were then placed on $11 \%$ SDSPolyacrylamide gel and enclosed with $0.5 \%$ agarose gel. Second dimension electrophoresis of reduced and alkylated samples was carried out using an Ettan Dalt twelve system (GE Healthcare). Electrophoresis was initially performed at $2 \mathrm{~W}$ for 45 minutes, followed by $110 \mathrm{~W}$ until the bromophenol blue dye reached the bottom edge of the gel.

Protein spots were visualized using protocols described in the PlusOne ${ }^{\text {max }}$ Silver staining kit (GE Healthcare). The complete protocol was followed for analytical gels. For preparative gels, a modified protocol was used. Glutaraldehyde was omitted from the sensitization step and formaldehyde omitted from the silver reaction step [51].

\section{Gel image analysis}

Following 2DE and silver staining, gels were scanned (Image Scanner III, GE Healthcare) and protein profiles compared using the ImageMaster Platinum 7.0 software (GE Healthcare). Protein spots were normalized using percentage volume. Statistical analysis for the comparison of protein abundance between the groups was performed by Student's t-test. Only protein spots with fold difference $>1.4$ and $p<0.05$ were considered to have significantly changed in abundance.

\section{Tryptic digestion}

Protein spots were excised and in-gel digested with trypsin (Promega) for mass spectrometric identification according to published protocols [52-54].

\section{MALDI-TOF/TOF mass spectrometry analysis and database searching}

Protein identification was performed as previously described using a MALDI-TOF mass spectrometer (ABI 4800 Plus, Applied Biosystems) [55,56].

\section{Bioinformatics}

Categorization of protein function was determined based on Swiss-Prot/TrEMBL database search. Ingenuity Pathway Analysis (IPA, www.ingenuity.com) was used to determine the localization of identified proteins and their participation in molecular networks involved in carcinogenesis according to the well-established Ingenuity Knowledge Base. Details regarding proteins that were different in abundance were exported to the IPA software. Each protein identifier was then mapped to its corresponding protein object and was overlaid onto a global molecular network developed from information contained in the Ingenuity Knowledge Base. Protein networks were then algorithmically generated based on their connectivity. A Right-tailed Fischer's exact test was used to calculate a p-value indicating the probability that each biological function assigned to the network is not due to chance alone.

\section{Real-time PCR (RTPCR)}

All experiments were performed according to manufacturers' instructions. Total mRNA was extracted from cell pellets using RNAqueous ${ }^{\circ}$-4PCR Kit (Ambion). High Capacity cDNA Reverse Transcription kit (Applied Biosystems) was used to reverse transcribe total mRNA into cDNA templates. RTPCR was performed by either Taqman ${ }^{\bullet}$ Gene Expression Assay or Fast Sybr Green (Applied Biosystems).

Primers were either designed using the Primer3 software or were based on literature and PrimerBank $[57,58]$. The specificity of primers was examined using NCBI primerBlast (www.ncbi.nlm.nih.gov/tools/primer-blast/). All PCR reactions were performed using the StepOnePlus RealTime PCR instrument (Applied Biosystems). PCR conditions were defined according to the manufacturer's recommended parameters. Gene expression levels were comparatively analyzed using StepOne software v2.2. Raw data from the experiments were recalculated as a mean expression level of cancer and normal groups to generalize 
the results of comparisons between the two groups. Student's unpaired $\mathrm{t}$-test was then performed to determine the significance of the results.

\section{Competing interest}

The authors declare that they have no competing interests.

\section{Authors' contributions}

SAK - principal investigator, designed and conceived the experiments, performed all MALDI-TOF/TOF analysis and prepared the manuscript. NAS - performed the experiments. RBZ - provided tissue samples from which cell lines were derived. SCC - established the cell cultures. MAR designed and conceived the experiments and prepared the manuscript All authors read and approved the final manuscript.

\section{Acknowledgements}

This project was funded by University of Malaya IPPP grant PS276/2010B and eScienceFund grant SF007-2013. This research had been facilitated by access to the University of Malaya Centre for Proteomics Research (UMCPR) and Medical Biotechnology Laboratory, Faculty of Medicine, University of Malaya. We gratefully acknowledge the staff of Oral Cancer Research \& Coordinating Center (OCRCC), University of Malaya for assistance in normal tissues collection and Cancer Research Initiatives Foundation (CARIF) for providing cell culture facilities and other necessary equipments.

\section{Author details}

'Institute of Biological Sciences, Faculty of Science, University of Malaya, 50603 Kuala Lumpur, Malaysia. ${ }^{2}$ Oral Cancer Research and Co-ordinating Centre \& Faculty of Dentistry, University of Malaya, 50603 Kuala Lumpur, Malaysia. ${ }^{3}$ Oral Cancer Research Team, 2nd Floor Outpatient Centre, Sime Darby Medical Centre, Cancer Research Initiatives Foundation (CARIF), 47500 Subang Jaya, Selangor, Malaysia. ${ }^{4}$ Department of Clinical Oral Biology, Faculty of Dentistry, Universiti Kebangsaan Malaysia, 50300 Kuala Lumpur, Malaysia. ${ }^{5}$ Department of Oral and Maxillofacial Surgery, Faculty of Dentistry, University of Malaya, 50603 Kuala Lumpur, Malaysia. ${ }^{6}$ University of Malaya Centre for Proteomics Research (UMCPR), University of Malaya, 50603 Kuala Lumpur, Malaysia.

Received: 10 July 2013 Accepted: 7 January 2014

Published: 15 January 2014

\section{References}

1. Kao S-Y, Chen Y-W, Chang K-W, Liu T-Y: Detection and screening of oral cancer and Pre-cancerous lesions. J Chin Med Assoc 2009, 72:227-233.

2. La Vecchia C, Tavani A, Franceschi S, Levi F, Corrao G, Negri E: Epidemiology and prevention of oral cancer. Oral Oncol 1997, 33:302-312.

3. Lo W-Y, Tsai M-H, Tsai Y, Hua C-H, Tsai F-J, Huang S-Y, Tsai C-H, Lai C-C: Identification of over-expressed proteins in oral squamous cell carcinoma (OSCC) patients by clinical proteomic analysis. Clin Chim Acta 2007, 376:101-107.

4. Zain RB: Cultural and dietary risk factors of oral cancer and precancer - a brief overview. Oral Oncol 2001, 37:205-210.

5. Craven RA, Stanley AJ, Hanrahan S, Dods J, Unwin R, Totty N, Harnden P, Eardley I, Selby PJ, Banks RE: Proteomic analysis of primary cell lines identifies protein changes present in renal cell carcinoma. Proteomics 2006, 6:2853-2864.

6. Hileman EO, Liu J, Albitar M, Keating MJ, Huang P: Intrinsic oxidative stress in cancer cells: a biochemical basis for therapeutic selectivity. Cancer Chemother Pharmacol 2004, 53:209-219.

7. Yossepowitch O, Pinchuk I, Gur U, Neumann A, Lichtenberg D, Baniel J: Advanced but not localized prostate cancer is associated with increased oxidative stress. J Urol 2007, 178:1238-1243. discussion 1243-1234.

8. Arsova-Sarafinovska Z, Eken A, Matevska N, Erdem O, Sayal A, Savaser A, Banev S, Petrovski D, Dzikova S, Georgiev V, et al: Increased oxidative/ nitrosative stress and decreased antioxidant enzyme activities in prostate cancer. Clin Biochem 2009, 42:1228-1235.

9. Creighton DJ, Zheng ZB, Holewinski R, Hamilton DS, Eiseman JL: Glyoxalase I inhibitors in cancer chemotherapy. Biochem Soc Trans 2003, 31:1378-1382.

10. Sakamoto H, Mashima T, Kizaki A, Dan S, Hashimoto Y, Naito M, Tsuruo T: Glyoxalase I is involved in resistance of human leukemia cells to antitumor agent-induced apoptosis. Blood 2000, 95:3214-3218.
11. Thornalley PJ: Protecting the genome: defence against nucleotide glycation and emerging role of glyoxalase I overexpression in multidrug resistance in cancer chemotherapy. Biochem Soc Trans 2003, 31:1372-1377.

12. Karihtala P, Mantyniemi A, Kang SW, Kinnula VL, Soini Y: Peroxiredoxins in breast carcinoma. Clin Cancer Res 2003, 9:3418-3424.

13. Primavera A, Fustinoni S, Biroccio A, Ballerini S, Urbani A, Bernardini S, Federici G, Capucci E, Manno M, Lo Bello M: Glutathione transferases and glutathionylated hemoglobin in workers exposed to Low doses of 1,3-butadiene. Cancer Epidemiol Biomarkers Prev 2008, 17:3004-3012.

14. Ansenberger-Fricano K, Mao M, Stadler K, Mason RP, Santos JH, Bonini M: Manganese superoxide dismutase overexpression leads to cancer cell survival. Free Radic Biol Med 2011, 51:S119.

15. Radenkovic S, Milosevic Z, Konjevic G, Karadzic K, Rovcanin B, Buta M, Gopcevic K, Jurisic V: Lactate dehydrogenase, catalase, and superoxide dismutase in tumor tissue of breast cancer patients in respect to mammographic findings. Cell Biochem Biophys 2013, 66:287-295.

16. Skrzycki M, Majewska M, Czeczot H: Superoxide dismutase mRNA and protein level in human colorectal cancer. Cen Eur J Biol 2010, 5:590-599.

17. Voorhees PM, Dees EC, O'Neil B, Orlowski RZ: The proteasome as a target for cancer therapy. Clin Cancer Res 2003, 9:6316-6325.

18. Lemaire R, Menguellet SA, Stauber J, Marchaudon V, Lucot JP, Collinet P, Farine MO, Vinatier D, Day R, Ducoroy P, et al: Specific MALDI imaging and profiling for biomarker hunting and validation: fragment of the $11 \mathrm{~S}$ proteasome activator complex, Reg alpha fragment, is a new potential ovary cancer biomarker. J Proteome Res 2007, 6:4127-4134.

19. Mistry SJ, Bank A, Atweh GF: Targeting stathmin in prostate cancer. Mol Cancer Ther 2005, 4:1821-1829.

20. Katayama M, Nakano H, Ishiuchi A, Wu W, Oshima R, Sakurai J, Nishikawa H, Yamaguchi S, Otsubo T: Protein pattern difference in the colon cancer cell lines examined by two-dimensional differential in-gel electrophoresis and mass spectrometry. Surg Today 2006, 36:1085-1093.

21. Almgren MA, Henriksson KC, Fujimoto J, Chang CL: Nucleoside diphosphate kinase $\mathrm{A} / \mathrm{nm} 23-\mathrm{H} 1$ promotes metastasis of NB69-derived human neuroblastoma. Mol Cancer Res 2004, 2:387-394.

22. Laine A, Topisirovic I, Zhai D, Reed JC, Borden KL, Ronai Z: Regulation of p53 localization and activity by Ubc13. Mol Cell Biol 2006, 26:8901-8913.

23. Dong $M$, Pang $X, X u Y$, Wen F, Zhang Y: Ubiquitin-conjugating enzyme 9 promotes epithelial ovarian cancer cell proliferation in vitro. Int J Mol SC 2013, 14:11061-11071.

24. Liang J, Nishi H, Bian ML, Higuma C, Sasaki T, Ito H, Isaka K: The ubiquitinconjugating enzyme E2-EPF is overexpressed in cervical cancer and associates with tumor growth. Oncol Rep 2012, 28:1519-1525.

25. Du H, Jie L, Xu W, Wu Y, Liu T, Li M: A monoclonal antibody against a potential cancer biomarker, human ubiquitin-conjugating enzyme E2. Hybridoma (Larchmt) 2012, 31:196-202.

26. Masuda Y, Maeda S, Watanabe A, Sano Y, Aiuchi T, Nakajo S, Itabe $H$, Nakaya K: A novel 21-kDa cytochrome c-releasing factor is generated upon treatment of human leukemia U937 cells with geranylgeraniol. Biochem Biophys Res Commun 2006, 346:454-460.

27. Najm MZ, Zaidi S, Siddiqui WA, Husain SA: Immunohistochemical expression and mutation study of prohibitin gene in indian female breast cancer cases. Med Oncol 2013, 30:614.

28. Zhang $\mathrm{L}$, Ji Q, Ni ZH, Sun J: Prohibitin induces apoptosis in BGC823 gastric cancer cells through the mitochondrial pathway. Asian Pac J Cancer Prev 2012, 13:3803-3807.

29. Semenzato M, Cogliati S, Scorrano L: Prohibitin(g) cancer: aurilide and killing by Opa1-dependent cristae remodeling. Chem Biol 2011, 18:8-9.

30. Wu TF, Wu H, Wang YW, Chang TY, Chan SH, Lin YP, Liu HS, Chow NH: Prohibitin in the pathogenesis of transitional cell bladder cancer. Anticancer Res 2007, 27:895-900.

31. Erlich RB, Kahn SA, Lima FR, Muras AG, Martins RA, Linden R, Chiarini LB, Martins VR, Moura Neto V: STI1 promotes glioma proliferation through MAPK and PI3K pathways. Glia 2007, 55:1690-1698.

32. Tsai CL, Tsai CN, Lin CY, Chen HW, Lee YS, Chao A, Wang TH, Wang HS, Lai CH: Secreted stress-induced phosphoprotein 1 activates the ALK2-SMAD signaling pathways and promotes cell proliferation of ovarian cancer cells. Cell Rep 2012, 2:283-293.

33. Wang TH, Chao A, Tsai CL, Chang CL, Chen SH, Lee YS, Chen JK, Lin YJ, Chang PY, Wang CJ, et al: Stress-induced phosphoprotein 1 as a secreted biomarker for human ovarian cancer promotes cancer cell proliferation. Mol Cell Proteomics 2010, 9:1873-1884. 
34. Kim S, Cho H, Nam EJ, Kim SW, Kim YT, Park YW, Kim BW, Kim JH: Autoantibodies against stress-induced phosphoprotein-1 as a novel biomarker candidate for ovarian cancer. Genes Chromosomes Cancer 2010, 49:585-595.

35. Li K, Yang J, Chen ZR: Relationships among interleukin-1beta, interleukin-1 receptor antagonist gene polymorphism and susceptibility to gastric cancer Sichuan Da Xue Xue Bao Yi Xue Ban 2010, 41:1039-1043.

36. He BS, Pan YQ, Xu YF, Zhu C, Qu LL, Wang SK: Polymorphisms in interleukin-1B (IL-1B) and interleukin 1 receptor antagonist (IL-1RN) genes associate with gastric cancer risk in the Chinese population. Dig Dis Sci 2011, 56:2017-2023.

37. Lurje G, Hendifar AE, Schultheis AM, Pohl A, Husain H, Yang D, Manegold PC, Ning Y, Zhang W, Lenz HJ: Polymorphisms in interleukin 1 beta and interleukin 1 receptor antagonist associated with tumor recurrence in stage II colon cancer. Pharmacogenet Genomics 2009, 19:95-102.

38. Yamashita T, Okamura T, Nagano K, Imai S, Abe Y, Nabeshi H, Yoshikawa T, Yoshioka Y, Kamada H, Tsutsumi Y, Tsunoda S: Rho GDP-dissociation inhibitor alpha is associated with cancer metastasis in colon and prostate cancer. Pharmazie 2012, 67:253-255.

39. Liu J, Zhang D, Luo W, Yu Y, Yu J, Li J, Zhang X, Zhang B, Chen J, Wu XR, et al: X-linked inhibitor of apoptosis protein (XIAP) mediates cancer cell motility via Rho GDP dissociation inhibitor (RhoGDI)-dependent regulation of the cytoskeleton. J Biol Chem 2011, 286:15630-15640.

40. Skalnikova H, Martinkova J, Hrabakova R, Halada P, Dziechciarkova M, Hajduch M, Gadher SJ, Hammar A, Enetoft D, Ekefjard A, et al: Cancer drug-resistance and a look at specific proteins: Rho GDP-dissociation inhibitor 2, Y-box binding protein 1, and HSP70/90 organizing protein in proteomics clinical application. J Proteome Res 2011, 10:404-415.

41. Lounsbury KM, Macara IG: Ran-binding protein 1 (RanBP1) forms a ternary complex with Ran and karyopherin beta and reduces Ran GTPaseactivating protein (RanGAP) inhibition by karyopherin beta. J Biol Chem 1997, 272:551-555.

42. Tohtong R, Phattarasakul K, Jiraviriyakul A, Sutthiphongchai T: Dependence of metastatic cancer cell invasion on MLCK-catalyzed phosphorylation of myosin regulatory light chain. Prostate Cancer Prostatic Dis 2003, 6:212-216.

43. Li DJ, Deng G, Xiao ZQ, Yao HX, Li C, Peng F, Li MY, Zhang PF, Chen YH, Chen ZC: Identificating 14-3-3 sigma as a lymph node metastasis-related protein in human lung squamous carcinoma. Cancer Lett 2009, 279:65-73.

44. Ozaki K, Kuroki T, Hayashi S, Nakamura Y: Isolation of three testis-specific genes (TSA303, TSA806, TSA903) by a differential mRNA display method. Genomics 1996, 36:316-319.

45. Wang JW, Peng SY, Li JT, Wang Y, Zhang ZP, Cheng Y, Cheng DQ, Weng $W H$, Wu XS, Fei $X Z$, et al: Identification of metastasis-associated proteins involved in gallbladder carcinoma metastasis by proteomic analysis and functional exploration of chloride intracellular channel 1. Cancer Lett 2009, 281:71-81

46. Tang HY, Beer LA, Tanyi JL, Zhang R, Liu Q, Speicher DW: Protein isoform-specific validation defines multiple chloride intracellular channel and tropomyosin isoforms as serological biomarkers of ovarian cancer. J Proteomics 2013, 89:165-178.

47. Petrova DT, Asif AR, Armstrong WW, Dimova I, Toshev S, Yaramov N, Oellerich $M$, Toncheva D: Expression of chloride intracellular channel protein 1 (CLIC1) and tumor protein D52 (TPD52) as potential biomarkers for colorectal cancer. Clin Biochem 2008, 41:1224-1236.

48. Suh KS, Mutoh M, Gerdes M, Yuspa SH: CLIC4, an intracellular chloride channel protein, is a novel molecular target for cancer therapy. J Investig Dermatol Symp Proc 2005, 10:105-109.

49. Hamid S, Lim KP, Zain RB, Ismail SM, Lau SH, Mustafa WM, Abraham MT, Nam NA, Teo SH, Cheong SC: Establishment and characterization of Asian oral cancer cell lines as in vitro models to study a disease prevalent in Asia. Int J Mol Med 2007, 19:453-460.

50. Chang HY, Hor SY, Lim KP, Zain RB, Cheong SC, Rahman MA, Karsani SA: Oral cancer secretome: identification of cancer associated proteins. Electrophoresis 2013, 34:2199-2208.

51. Yan JX, Wait R, Berkelman T, Harry RA, Westbrook JA, Wheeler CH, Dunn MJ: A modified silver staining protocol for visualization of proteins compatible with matrix-assisted laser desorption/ionization and electrospray ionizationmass spectrometry. Electrophoresis 2000, 21:3666-3672.

52. Jeno P, Mini T, Moes $S$, Hintermann E, Horst M: Internal sequences from proteins digested in polyacrylamide gels. Anal Biochem 1995, 224:75-82.
53. Shevchenko A, Wilm M, Vorm O, Mann M: Mass spectrometric sequencing of proteins silver-stained polyacrylamide gels. Anal Chem 1996, 68:850-858.

54. Wilm M, Shevchenko A, Houthaeve T, Breit S, Schweigerer L, Fotsis T, Mann M: Femtomole sequencing of proteins from polyacrylamide gels by nano-electrospray mass spectrometry. Nature 1996, 379:466-469.

55. Heng EC, Karsani SA, Abdul Rahman M, Abdul Hamid NA, Hamid Z, Wan Ngah WZ: Supplementation with tocotrienol-rich fraction alters the plasma levels of Apolipoprotein A-I precursor, Apolipoprotein $E$ precursor, and C-reactive protein precursor from young and old individuals. Eur J Nutr 2013, 52:1811-1820.

56. Thio CL, Yusof R, Abdul-Rahman PS, Karsani SA: Differential proteome analysis of chikungunya virus infection on host cells. PLOS One 2013, 8:e61444.

57. Spandidos A, Wang X, Wang H, Seed B: PrimerBank: a resource of human and mouse PCR primer pairs for gene expression detection and quantification. Nucleic Acids Res 2010, 38:D792-D799.

58. He Y, Brown MA, Rothnagel JA, Saunders NA, Smith R: Roles of heterogeneous nuclear ribonucleoproteins $A$ and $B$ in cell proliferation. J Cell Sci 2005, 118:3173-3183.

doi:10.1186/1477-5956-12-3

Cite this article as: Karsani et al:: Comparative proteomics analysis of oral cancer cell lines: identification of cancer associated proteins. Proteome Science 2014 12:3.

\section{Submit your next manuscript to BioMed Central and take full advantage of:}

- Convenient online submission

- Thorough peer review

- No space constraints or color figure charges

- Immediate publication on acceptance

- Inclusion in PubMed, CAS, Scopus and Google Scholar

- Research which is freely available for redistribution

Submit your manuscript at www.biomedcentral.com/submit
C) Biomed Central 